\title{
Can a local, PKM $\xi$ dependent translational switch account for the maintenance of synaptic plasticity?
}

\author{
Naveed Aslam*, Harel Z Shouval \\ From Nineteenth Annual Computational Neuroscience Meeting: CNS*2010 \\ San Antonio, TX, USA. 24-30 July 2010
}

\begin{abstract}
Memory can last a human lifetime, yet at the synaptic level it is encoded by proteins that turnover at rates that are much faster than the lifetime of memory. A critical open question in the neuroscience of learning and memory is how memory and its cellular basis synaptic plasticity can be maintained for longer than its molecular substrates. Recently it has been shown that the activity of a brain specific kinase, $\mathrm{PKM} \xi$, is necessary for the maintenance but not the induction of synaptic plasticity. It is also known that synthesis of new proteins is necessary for inducing long lasting synaptic plasticity and memory. We postulate that a molecular network that includes activation, translation and degradation of PKM $\xi$ can be a bi-stable molecular switch, that can account for the maintenance of long-term synaptic plasticity and memory. We formulate a mathematical model of such a molecular network, and show that it can be bi-stable and that it accounts for many of the experimental observations regarding the activation, synthesis and inhibition of PKM $\xi$. Our model also makes testable experimental predictions.
\end{abstract}

Submit your next manuscript to BioMed Central and take full advantage of:

- Convenient online submission

- Thorough peer review

- No space constraints or color figure charges

- Immediate publication on acceptance

- Inclusion in PubIMed, CAS, Scopus and Google Scholar

- Research which is freely available for redistribution 